\title{
A Hemalog D analysis of chronic lymphocytic leukaemia and other lymphoproliferative disorders affecting the blood
}

\author{
KG PATTERSON, AH GOLDSTONE, JDM RICHARDS, JC CAWLEY \\ From the Department of Haematology, University College Hospital, London WCIE 6AU
}

SUMMARY A correlative clinical and Hemalog D study of 80 cases of chronic lymphocytic leukaemia (CLL) was performed and the results compared with those in other lymphoproliferative disorders affecting the blood (eight cases of hairy-cell leukaemia, HCL; three cases of prolymphocytic leukaemia, PLL; two cases of lymphoplasmacytoid proliferation, LPP; and one case of Sézary's syndrome, SS). In CLL the mean percentage and absolute counts of large unstained cells (LUC) were $8.7 \%$ and $6.2 \times 10^{9} / 1\left(6200 / \mathrm{mm}^{3}\right)$, and the percentage of LUCs was not substantially affected by treatment; there was no correlation between LUCs and Rai clinical stage. SS and LPP were characterised by a similar percentage of LUCs, but both HCL and PLL were distinguished by a higher mean percentage of LUCs. Stage IV CLL was associated with monocytopenia, but other stages of CLL, PLL, LPP, and SS showed no consistent reduction of absolute numbers of nonlymphoid cell types. In contrast, HCL was characterised by a consistent absolute neutropenia and monocytopenia which distinguished its Hemalog D profile from that of PLL.

The value of clinical staging in the prognosis of chronic lymphocytic leukaemia (CLL) is now well established. ${ }^{2}$ However, the relation between the morphology of the peripheral blood lymphocytes and clinical stage and prognosis is controversial. ${ }^{3}$ Some of this controversy may be attributable to the subjectivity inherent in microscopical examination.

In this study we used an automated differential counter (the Hemalog D) to provide a purely objective assessment of cell size in CLL, and related the results to clinical staging. The Hemalog $D$ counts large numbers of cells (30000 per sample) and identifies leucocytes by their size and specific cytochemistry. The machine therefore provides precise counts of minor leucocyte populations and consequently the study allowed analysis of the relation between these cell counts and clinical stage-a subject that has received scant attention, probably because of the difficulty in obtaining precise manual counts of minor leucocyte populations. Finally, we compared the Hemalog D findings in CLL with those in a variety of other lymphoproliferative disorders affecting the blood.

Accepted for publication 9 October 1980

\section{Patients and methods}

PATIENTS

Peripheral blood was examined from 80 cases of CLL, 8 cases of hairy-cell leukaemia (HCL), 3 cases of prolymphocytic leukaemia (PLL), 2 cases of lymphoplasmacytoid proliferation (LPP), and 1 case of Sézary's syndrome (SS). The CLL patients were assigned to one of the five (0-IV) Rai clinical stages ${ }^{1}$ according to the clinical and haematological findings at the time of Hemalog $\mathrm{D}$ analysis. Thirty-two patients were untreated and 48 had received chemotherapy. Patients were regarded as untreated if they had received no treatment for two years before analysis. Treated patients had usually received intermittent low doses of chlorambucil with or without steroid, but a few patients had received more vigorous chemotherapy with courses of cyclophosphamide, vincristine, and prednisone. In the 54 CLL patients whose history was available the clinical stage at the time of Hemalog D analysis was the same as that at presentation in all but 11 cases. For the main analysis, when patients were tested sequentially, the means of the results were determined, provided the patient remained untreated or continued the same treatment. 
None of the other patients with lymphoproliferative disorders had received chemotherapy, but six of the eight patients with HCL had had a splenectomy.

\section{HEM A L OG D}

The principles and technical aspects of the operation of the Hemalog D have been described in detail. ${ }^{45}$ In brief, the machine accurately identifies individual leucocyte types on the basis of their cell size and staining for peroxidase, esterase, and alcian blue. Lymphocytes (peroxidase-negative cells) that are larger than normal lymphocytes are counted by the machine as large unstained cells (LUCs). When the instrument is unable to identify a clearly defined neutrophil population, it indicates this with a low peroxidase alarm; when this occurs the neutrophil count is uncertain but is usually low. EDTA-anticoagulated whole-blood samples were used and were processed within 24 hours, but usually with in 12 hours.

\section{Determination of modal lymphocyte size in CLL}

The Hemalog $\mathrm{D}$ may be used to provide a histogram of cell size (determined by light scatter) and cell numbers (Fig. 1). In 21 cases the oscilloscope display was photographed and the negative projected on to graph paper to read off the modal cell size. The reading obtained (in volts) reflects cell size (as measured by light scatter), but is not readily converted to units of volume.

\section{Results}

LARGE UNSTAINED CELLS IN CLL

The absolute count of LUCs was raised in all 80 patients: range $0.43-30.5 \times 10^{9} / 1\left(430-30500 / \mathrm{mm}^{3}\right)$; normal range 0.06-0.25 $\times 10^{9} / 1\left(60-250 / \mathrm{mm}^{3}\right)$, and the percentage of LUCs elevated : range $3 \cdot 3-18 \cdot 8 \%$; nor- mal range $0 \cdot 8-3 \cdot 1 \%$, in all but one patient (treated stage I). Although the percentage of LUCs was lower in : stage 0 disease, there were no statistically significan $\overrightarrow{\overrightarrow{5}}$ differences in the percentage of LUCs among the different clinical stages (Table 1). The mean whit\& blood cell (WBC) count rose with clinical stage, buen so did the standard deviation of the WBC counts, soo that there was no statistically significant difference between the stages. Because of this rising WBC count ${ }^{\text {s }}$ the mean absolute LUC count also rose with stage? When, in order to allow for variations in granulocyte count, the absolute LUC count was expressed as percentage of the absolute total lymphoid count im the way suggested by Binet et al., ${ }^{3}$ no significantw differences were noted between the different clinical stages.

When the patients were analysed according tow whether or not they had received treatment (Tableso 2 and 3 ), substantially similar results were obtained $;$ again, there were no statistically significant dif $z$ ferences in the percentage of LUCs or absolute LUQ counts among the different clinical stages. Severato patients were examined before and after the intro $\stackrel{0}{\rightarrow}$ duction of low-dose chlorambucil (the results obtained after treatment in such cases were noto included in the analysis given above) and although there were some exceptions, when treatment caused the WBC count to fall the percentage of LUCs dido not fall.

MODAL CELL SIZE IN CLL AND ITS RELATION TO LUCS

It was possible to identify a modal cell-size peak in 18 out of 20 cases examined (Fig. 1a). Measurementō of modal cell size correlated with the percentage of LUCs $(r=0.67 ; p<0.01)$. In two cases the lympho-3. cyte population showed no clear size peak so that it was not possible to determine a modal cell size (Fig.

Table 1 Hemalog $D$ data in all patients with CLL

\begin{tabular}{|c|c|c|c|c|c|c|c|c|c|c|}
\hline \multirow{2}{*}{$\begin{array}{l}\text { Rai } \\
\text { clinical } \\
\text { stage* }\end{array}$} & \multirow{2}{*}{$\begin{array}{l}\text { No. of } \\
\text { cases }\end{array}$} & \multirow{2}{*}{\multicolumn{2}{|c|}{$\begin{array}{l}W B C \quad L U C \\
\left(\times 10^{\circ} / l(\% \pm\right. \\
\left. \pm S D)_{+}^{+} S D\right) \dagger\end{array}$}} & \multicolumn{6}{|c|}{ Absolute counts $\left(\times 10^{9} / 1 \pm S D\right)_{+}^{+}$} & \multirow{2}{*}{$\begin{array}{l}\% \text { (absolute LUCl } \\
\text { absolute lymphocytes } \\
\text { absolute LUC) } \pm S D\end{array}$} \\
\hline & & & & Neutrophils & Lymphocytes & Monocytes & Eosinophils & Basophils & $L U C$ & \\
\hline \multirow[t]{2}{*}{0} & 10 & $28 \cdot 8$ & $6 \cdot 2$ & $5 \cdot 2$ & $20 \cdot 5$ & 0.53 & 0.45 & 0.06 & $2 \cdot 0$ & $8 \cdot 3$ \\
\hline & & \pm 20.2 & $\pm \mathbf{2 \cdot 7}$ & $\pm 1 \cdot \overline{7}$ & \pm 15.9 & \pm 0.34 & \pm 0.51 & \pm 0.06 & $\begin{array}{r}1.9 \\
+1\end{array}$ & \pm 3.6 \\
\hline \multirow[t]{2}{*}{ I } & 24 & $43 \cdot 0$ & $8 \cdot 5$ & 4.8 & $32 \cdot 2$ & 0.31 & 0.14 & 0.05 & $4 \cdot 2$ & $10 \cdot 7$ \\
\hline & & \pm 39.9 & \pm 3.4 & $\pm 2 \cdot 3$ & +31.8 & \pm 0.22 & \pm 0.12 & \pm 0.04 & \pm 5.5 & $\pm \mathbf{3 . 8}$ \\
\hline \multirow[t]{2}{*}{ II } & 27 & $68 \cdot 3$ & $9 \cdot 2$ & 4.8 & 51.0 & 0.29 & 0.09 & 0.04 & $7 \cdot 4$ & 11.4 \\
\hline & & \pm 87.0 & $\pm 4 \cdot 3$ & $\pm \mathbf{3 . 0}$ & \pm 60.7 & \pm 0.26 & \pm 0.11 & \pm 0.04 & $\pm 10 \cdot 2$ & $\pm 4 \cdot 7$ \\
\hline \multirow[t]{2}{*}{ III } & 9 & 79.5 & 9.4 & 5.0 & 61.8 & 0.19 & 0.04 & 0.04 & $8 \cdot 8$ & 10.8 \\
\hline & & \pm 69.7 & \pm 4.9 & $\pm 2 \cdot 4$ & \pm 53.8 & \pm 0.47 & \pm 0.08 & \pm 0.07 & $\pm \mathbf{9 \cdot 7}$ & \pm 5.5 \\
\hline \multirow[t]{2}{*}{ IV } & 10 & 93.8 & $9 \cdot 3$ & 3.5 & $78 \cdot 7$ & 0.11 & $\mathbf{0 . 0 7}$ & 0.02 & $9 \cdot 3$ & $10 \cdot 7$ \\
\hline & & \pm 94.6 & $\pm 4 \cdot 6$ & $\pm 1 \cdot 7$ & $\pm 81 \cdot 8$ & \pm 0.11 & $\pm \mathbf{0 . 0 7}$ & \pm 0.03 & \pm 9.5 & \pm 3.8 \\
\hline Total & 80 & $\begin{array}{r}60 \cdot 2 \\
+70 \cdot 3\end{array}$ & $\begin{array}{r}8 \cdot 7 \\
+4 \cdot 0\end{array}$ & $\begin{array}{r}4 \cdot 7 \\
+2 \cdot 4\end{array}$ & $\begin{array}{r}46 \cdot 2 \\
+53.9\end{array}$ & 0.29 & $0 \cdot 14$ & 0.05 & $6 \cdot 2$ & $10 \cdot 6$ \\
\hline
\end{tabular}

*As defined by Rai et al., 1975.1

†The Hemalog D prints percentage counts for individual leucocyte types, but for brevity only the percentage of LUCs are given. $\ddagger$ Conversion: SI to traditional units-1 $1 \times 10^{9} / 1 \approx 1000 / \mathrm{mm}^{3}$. 
Table 2 Hemalog D data in untreated patients with $C L L$

\begin{tabular}{|c|c|c|c|c|c|c|c|c|c|c|}
\hline \multirow{2}{*}{$\begin{array}{l}\text { Rai } \\
\text { clinical } \\
\text { stage* }\end{array}$} & \multirow{2}{*}{$\begin{array}{l}\text { No. of } \\
\text { cases }\end{array}$} & \multirow{2}{*}{$\begin{array}{l}W B C \\
\left(\times 10^{9} / 1\right. \\
\pm S D) \ddagger\end{array}$} & \multirow{2}{*}{$\begin{array}{l}L U C \\
(\% \pm \\
S D) \dagger\end{array}$} & \multicolumn{6}{|c|}{ Absolute counts $\left(\times 10^{\circ} / 1 \pm S D\right) \ddagger$} & \multirow{2}{*}{$\begin{array}{l}\% \text { (absolute LUCl } \\
\text { absolute lymphocytes }+ \\
\text { absolute LUC) } \pm S D\end{array}$} \\
\hline & & & & Neutrophils & Lymphocytes & Monocytes & Eosinophils & Basophils & $L U C$ & \\
\hline 0 & 8 & $\begin{array}{r}23.5 \\
+15.3\end{array}$ & $\begin{array}{r}5.9 \\
\pm 2.9\end{array}$ & $\begin{array}{r}4 \cdot 8 \\
\pm 1 \cdot 2\end{array}$ & $\begin{array}{r}16.4 \\
\pm 12.8\end{array}$ & $\begin{array}{r}0.55 \\
\pm 0.35\end{array}$ & $\begin{array}{r}0.44 \\
\pm 0.57\end{array}$ & $\begin{array}{r}0.07 \\
\pm 0.06\end{array}$ & $\begin{array}{r}1.5 \\
\pm 1.4\end{array}$ & $\begin{array}{r}8 \cdot 2 \\
\pm 4 \cdot 0\end{array}$ \\
\hline I & 10 & $\begin{array}{r}69 \cdot 8 \\
+45 \cdot 7\end{array}$ & $\begin{array}{r}9 \cdot 3 \\
+3 \cdot 7\end{array}$ & $\begin{array}{r}6.3 \\
+2.7\end{array}$ & $\begin{array}{r}43.6 \\
+32.3\end{array}$ & $\begin{array}{r}0.27 \\
+0.21\end{array}$ & $\begin{array}{r}0.12 \\
+0.13\end{array}$ & $\begin{array}{r}0.05 \\
+0.06\end{array}$ & $\begin{array}{r}7 \cdot 1 \\
+6 \cdot 8\end{array}$ & $\begin{array}{r}10 \cdot 8 \\
+4 \cdot 0\end{array}$ \\
\hline II & 11 & 66.2 & $11 \cdot 2$ & 4.9 & 50.3 & 0.23 & 0.09 & 0.04 & 8.9 & $\begin{array}{l} \pm 4 \cdot 0 \\
13 \cdot 1\end{array}$ \\
\hline & & \pm 59.9 & $\pm 5 \cdot 2$ & $\pm \mathbf{3 \cdot 2}$ & \pm 46.4 & \pm 0.26 & $\pm 0 \cdot 14$ & \pm 0.04 & $\pm 9 \cdot 8$ & $\pm 5 \cdot 2$ \\
\hline III & 3 & $112 \cdot 8$ & $8 \cdot 4$ & $6 \cdot 1$ & $86 \cdot 3$ & 0.03 & 0 & 0.04 & $12 \cdot 7$ & $9 \cdot 7$ \\
\hline & & $\pm 117 \cdot 5$ & $\pm 4 \cdot 8$ & $\pm 3 \cdot 1$ & $\pm 90 \cdot 3$ & \pm 0.05 & & \pm 0.06 & $\pm 16 \cdot 3$ & $\pm 4 \cdot 8$ \\
\hline IV & 0 & - & - & - & - & - & - & - & - & - \\
\hline Total & 32 & $\begin{array}{r}61.0 \\
\pm 58.0\end{array}$ & $\begin{array}{r}9.0 \\
\pm 4.5\end{array}$ & $\begin{array}{r}5 \cdot 3 \\
\pm 2.5\end{array}$ & $\begin{array}{r}46.3 \\
\pm 45.2\end{array}$ & $\begin{array}{r}0.30 \\
\pm 0.30\end{array}$ & $\begin{array}{r}0.18 \\
\pm 0.33\end{array}$ & $\begin{array}{r}0.05 \\
\pm 0.05\end{array}$ & $\begin{array}{r}6.8 \\
\pm 8 \cdot 7\end{array}$ & $\begin{array}{r}10 \cdot 8 \\
\pm 4 \cdot 7\end{array}$ \\
\hline
\end{tabular}

*As defined by Rai et al., 1975. ${ }^{1}$

†The Hemalog D prints percentage counts for individual leucocyte types, but for brevity only the parcentage of LUCs are given.

$\ddagger$ Conversion: SI to traditional units-1 $1 \times 10^{\circ} / 1 \approx 1000 / \mathrm{mm}^{3}$.

Table 3 Hemalog D data in treated patients with CLL

\begin{tabular}{|c|c|c|c|c|c|c|c|c|c|c|}
\hline \multirow{2}{*}{$\begin{array}{l}\text { Rai } \\
\text { clinical } \\
\text { stage* }\end{array}$} & \multirow{2}{*}{$\begin{array}{l}\text { No. of } \\
\text { cases }\end{array}$} & \multirow{2}{*}{$\begin{array}{l}W B C \\
\left(\times 10^{9} / l\right. \\
\pm S D)_{\ddagger}^{\ddagger}\end{array}$} & \multirow{2}{*}{$\begin{array}{l}L U C \\
(\% \pm \\
S D) \dagger\end{array}$} & \multicolumn{6}{|c|}{ Absolute counts $\left(\times 10^{\circ} / l \pm S D\right) \ddagger$} & \multirow{2}{*}{$\begin{array}{l}\% \text { (absolute LUCl } \\
\text { absolute lymphocytes }+ \\
\text { absolute LUC) } \pm S D\end{array}$} \\
\hline & & & & Neutrophils & Lymphocytes & Monocytes & Eosinophils & Basophils & $L U C$ & \\
\hline $\mathbf{0}$ & 2 & $\begin{array}{r}50.0 \\
+30.5\end{array}$ & $\begin{array}{r}5.1 \\
+0.4\end{array}$ & $\begin{array}{r}6.9 \\
+3.1\end{array}$ & $\begin{array}{r}36.7 \\
+22 \cdot 1\end{array}$ & $\begin{array}{r}0.46 \\
+0.44\end{array}$ & $\begin{array}{r}0.50 \\
+0.31\end{array}$ & $\begin{array}{r}0.06 \\
\pm 0.06\end{array}$ & $\begin{array}{r}3.9 \\
+3.4\end{array}$ & $\begin{array}{r}8.8 \\
+2.8\end{array}$ \\
\hline I & 14 & $\begin{array}{r}23.8 \\
+20.6\end{array}$ & $\begin{array}{r}7.9 \\
+3.3\end{array}$ & $\begin{array}{r}4.0 \\
\pm 1.6\end{array}$ & $\begin{array}{r}16.0 \\
\pm 17.0\end{array}$ & $\begin{array}{r}0.34 \\
\pm 0.23\end{array}$ & $\begin{array}{r}0.15 \\
+0.10\end{array}$ & $\begin{array}{r}0.05 \\
+0.03\end{array}$ & $\begin{array}{r}2.2 \\
\pm 3.1\end{array}$ & $\begin{array}{r}10.6 \\
+3.4\end{array}$ \\
\hline II & 16 & $\begin{array}{r}69.7 \\
+103.5\end{array}$ & $\begin{array}{r}7.9 \\
+3.1\end{array}$ & $\begin{array}{r}4.8 \\
+3.0\end{array}$ & $\begin{array}{r}51.5 \\
+70.4\end{array}$ & $\begin{array}{r}0.33 \\
\pm 0.26\end{array}$ & $\begin{array}{r}0.09 \\
+0.09\end{array}$ & $\begin{array}{r}0.03 \\
\pm 0.04\end{array}$ & $\begin{array}{r}6.3 \\
+10.7\end{array}$ & $\begin{array}{r}10.2 \\
\pm 4.2\end{array}$ \\
\hline III & 6 & $\begin{array}{r}62.9 \\
+35.3\end{array}$ & $\begin{array}{r}9.9 \\
+5.4\end{array}$ & $\begin{array}{r}4.5 \\
+2 \cdot 3\end{array}$ & $\begin{array}{r}49.5 \\
\pm 28.7\end{array}$ & $\begin{array}{r}0.27 \\
\pm 0.57\end{array}$ & $\begin{array}{r}0.06 \\
\pm 0.10\end{array}$ & $\begin{array}{r}0.04 \\
\pm 0.07\end{array}$ & $\begin{array}{r}6.9 \\
+5.5\end{array}$ & $\begin{array}{r}11.4 \\
\pm 6.2\end{array}$ \\
\hline IV & 10 & $\begin{array}{r}93.8 \\
\pm 94.6\end{array}$ & $\begin{array}{r}9.3 \\
\pm 4.6\end{array}$ & $\begin{array}{r}3.5 \\
\pm 1.7\end{array}$ & $\begin{array}{r}78.7 \\
\pm 81.8\end{array}$ & $\begin{array}{r}0.11 \\
\pm 0.11\end{array}$ & $\begin{array}{r}0.07 \\
\pm 0.07\end{array}$ & $\begin{array}{r}0.02 \\
\pm 0.03\end{array}$ & $\begin{array}{r}9 \cdot 3 \\
\pm 9.5\end{array}$ & $\begin{array}{r}10.8 \\
\pm 4.7\end{array}$ \\
\hline Total & 48 & $\begin{array}{r}59.7 \\
\pm 78.0\end{array}$ & $\begin{array}{r}8.5 \\
\pm 3.6\end{array}$ & $\begin{array}{r}4 \cdot 3 \\
\pm 2 \cdot 3\end{array}$ & $\begin{array}{r}46.2 \\
\pm 59.4\end{array}$ & $\begin{array}{r}0.28 \\
\pm 0.29\end{array}$ & $\begin{array}{r}0.12 \\
\pm 0.13\end{array}$ & $\begin{array}{r}0.05 \\
\pm 0.11\end{array}$ & $\begin{array}{r}5 \cdot 7 \\
\pm 8 \cdot 2\end{array}$ & $\begin{array}{r}10.5 \\
\pm 4.5\end{array}$ \\
\hline
\end{tabular}

*As defined by Rai et al., $1975 .^{1}$

†The Hemalog D prints percentage counts for individual leucocyte types, but for brevity only the percentage of LUCs are given.

$\ddagger$ Conversion: SI to traditional units-1 $1 \times 10^{\circ} / 1 \approx 1000 / \mathrm{mm}^{3}$.

1b). In many of the cases the lymphocyte size distribution was not symmetrical (Fig. 1c) and therefore it was only possible to measure the modal cell size which did not correspond to the mean cell size.

\section{NON-LYMPHOID MINOR LEUCOCYTE}

POPULATIONS IN CLL

The mean absolute neutrophil count was normal in all stages of disease, and no marked differences were observed between the different stages, although the lowest mean absolute count was seen in stage IV patients. Similarly, there was no marked difference between treated and untreated patients. As the total WBC count increased with stage the percentage of neutrophils showed a corresponding decrease, resulting in a relatively constant absolute neutrophil count. Despite the absence of neutropenia in the groups as a whole, seven cases were neutropenic $\left(<2 \times 10^{9} / 1 ;<2000 / \mathrm{mm}^{3}\right)(5$ of these had been treated and they were distributed among all the clinical stages except 0 ). In addition, a low peroxidase alarm (see Methods) was present in seven cases and, because of the uncertainty concerning the neutrophil count in these patients, they were excluded from the analysis of neutrophils in CLL.

The mean absolute monocyte count became progressively reduced with advancing clinical stage, but absolute monocytopenia $\left(<0.15 \times 10^{9} / 1 ;<150 /\right.$ $\mathrm{mm}^{3}$ ) was observed only in stage IV disease. Treatment had no significant effect on the absolute monocyte count in stage 0 -III disease (all stage IV cases had had treatment). Thirty-two of the 80 patients were monocytopenic; these cases were distributed among all the clinical stages except 0 , but were particularly common in stage III and IV disease.

The mean absolute eosinophil count was normal $\left(>0.03 \times 10^{9} / 1 ;>30 / \mathrm{mm}^{3}\right)$ in all clinical stages, and there were no marked differences between treated and untreated patients or between clinical stages, except that stage 0 disease had a higher count. 

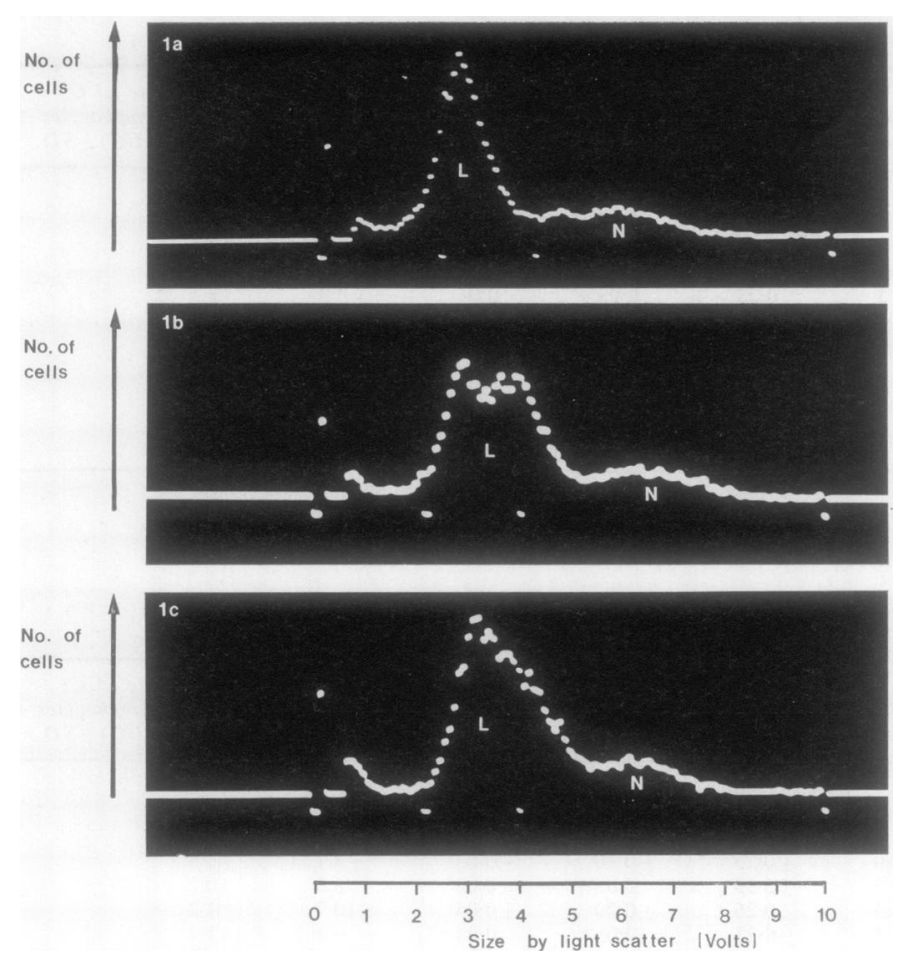

Histograms of cell size versus cell number in CLL photographed from the oscilloscope display of the Hemalog D. $\vec{\circ}$ (a) Shows a symmetrical lymphocyte (L) size distribution with a sharp peak representing modal cell size. (b) Shows a poorly defined lymphocyte $(L)$ size peak: this pattern was seen in 2 of the 21 cases and no attempt was made to derive a modal cell size in these cases. (c) Shows the sharply peaked, but skewed, distribution of lymphocyte $(L)$ size frequently observed in $C L L$. In all three displays a small neutrophil population $(N)$ is seen.
The mean absolute basophil count decreased with increasing clinical stage, but was normal $(>0.01 \times$ $10^{9} / 1 ;>10 / \mathrm{mm}^{3}$ ) in all stages.

\section{LUCS IN OTHER LYMPHOPROLIFERATIVE DISORDERS}

In HCL, the percentage of LUCs was invariably increased $(8-60 \%)$ and was in general much higher than in CLL (Table 4). In contrast to CLL, the percentage of LUCs increased with the WBC count. The WBC count in turn reflected the hairy-cell count, raised WBC counts invariably being associated with a high percentage of hairy cells. The three cases with less than $10 \%$ LUCs also had less than
$10 \%$ hairy cells. PLL was characterised by a hig/P percentage of LUCs $(13.9-46.4 \%)$ and high absolute $\left(9 \cdot 4-131 \times 10^{9} / 1 ; 9400-131000 / \mathrm{mm}^{3}\right)$ LUC counts while these were only moderately raised in LPP and SS. Apparent bimodal populations (with respect to. size) of lymphoid cells were observed in the case of SS and in one of the patients with HCL.

\section{NON-LYMPHOID MINOR LEUCOCYTE}

POPULATIONS IN LYMPHOPROLIFERATIVE DISORDERS

All cases of HCL were neutropenic $\left(0.25-1.4 \times 10^{9} / 1 ?\right.$ $250-1400 / \mathrm{mm}^{3}$ ), and with one exception (a patient with a very high WBC count after splenectomy) were

Table 4 Hemalog D data in other lymphoproliferative disorders

\begin{tabular}{|c|c|c|c|c|c|c|c|c|c|c|}
\hline \multirow[t]{2}{*}{ Diagnosis } & \multirow{2}{*}{$\begin{array}{l}\text { No. of } \\
\text { cases }\end{array}$} & \multirow{2}{*}{$\begin{array}{l}W B C \\
\left(\times 10^{9} / l\right. \\
\pm S D) \dagger\end{array}$} & \multirow{2}{*}{$\begin{array}{l}L U C \\
(\% \pm \\
S D)^{*}\end{array}$} & \multicolumn{6}{|c|}{ Absolute counts $\left(\times 10^{9} / l \pm S D\right) \dagger$} & \multirow{2}{*}{$\begin{array}{l}\% \text { (absolute LUCl } \\
\text { absolute lymphocytes } \\
\text { absolute LUC) } \pm S D\end{array}$} \\
\hline & & & & $\begin{array}{l}\text { Neutro- } \\
\text { phils }\end{array}$ & $\begin{array}{l}\text { Lympho- } \\
\text { cytes }\end{array}$ & $\begin{array}{l}\text { Mono- } \\
\text { cytes }\end{array}$ & $\begin{array}{l}\text { Eosino- } \\
\text { phils }\end{array}$ & $\begin{array}{l}\text { Baso- } \\
\text { phils }\end{array}$ & $L U C$ & \\
\hline \multirow{6}{*}{$\begin{array}{l}\text { Hairy-cell } \\
\text { leukaemia } \\
\text { Prolymphocytic } \\
\text { leukaemia } \\
\text { Lymphoplasma- } \\
\text { cytoid proliferation } \\
\text { Sézary's syndrome }\end{array}$} & 8 & $19 \cdot 2$ & $26 \cdot 9$ & 0.93 & $17 \cdot 7$ & 0.07 & 0.04 & 0.01 & $6 \cdot 6$ & $31 \cdot 1$ \\
\hline & & \pm 32.9 & \pm 19.4 & \pm 0.39 & $\pm 12 \cdot 4$ & $\pm \mathbf{0 . 0 9}$ & \pm 0.29 & $\pm \mathbf{0 . 0 1}$ & $\pm 11 \cdot 1$ & \pm 21.4 \\
\hline & 3 & 219 & 26.5 & 14.0 & 133 & $1 \cdot 1$ & 0.51 & 0.37 & $66 \cdot 5$ & $29 \cdot 0$ \\
\hline & & \pm 131 & $\pm 17 \cdot 4$ & \pm 9.9 & \pm 85 & \pm 0.6 & \pm 0.77 & \pm 0.40 & $\pm 61 \cdot 1$ & $\pm 20 \cdot 2$ \\
\hline & 2 & 18.6 & 10.5 & $5 \cdot 2$ & 11.4 & 0.57 & 0.07 & 0.02 & $1 \cdot 8$ & $15 \cdot 5$ \\
\hline & 1 & $51 \cdot 0$ & $10 \cdot 0$ & $3 \cdot 4$ & $40 \cdot 8$ & 0 & $\mathbf{0}$ & 0.05 & $5 \cdot 1$ & $11 \cdot 0$ \\
\hline
\end{tabular}

*The Hemalog D prints percentage counts for individual leucocyte types, but for brevity only the percentage of LUCs are given. †Conversion: SI to traditional units $-1 \times 10^{\circ} / 1 \approx 1000 / \mathrm{mm}^{3}$. 
monocytopenic $\left(<0.07 \times 10^{9} / 1 ;<70 / \mathrm{mm}^{3}\right)$. There was no reduction in the mean percentage and absolute numbers of eosinophils and basophils in HCL. In contrast, in PLL absolute neutrophil, eosinophil, and basophil counts were normal or raised.

\section{Discussion}

In this study of CLL we detected no correlation between the numbers of large lymphocytes present (as reflected by LUCs) and Rai clinical stage and therefore prognosis. ${ }^{1}$ The numbers of LUCs generally reflected modal lymphocyte size, and it is therefore probable that there is no relation in CLL between lymphocyte size, stage, and prognosis. Previous studies of lymphocyte morphology in CLL have yielded conflicting results. Some authors have claimed that the presence of larger lymphocytes is associated with a more advanced clinical stage and with a poor prognosis. ${ }^{367}$ Others have claimed that there is no correlation between lymphocyte morphology and prognosis. ${ }^{8}$ Peterson et al. ${ }^{910}$ correlated the presence of large reactive lymphocytes with a better prognosis. Since the reactive lymphocytes of infectious mononucleosis are detected by the Hemalog D as LUCs, ${ }^{11}$ it is likely that such "reactive" CLL lymphocytes would be detected as LUCs. Our study therefore was unable to confirm the findings of Peterson and colleagues. Similarly, we were unable to confirm the only previous Hemalog D study of CLL which showed that a ratio of absolute LUCs to total lymphocytes $>11.2 \%$ was associated with more advanced clinical disease. ${ }^{3}$ We were unable to account for the discrepancy between our results and those of Binet et al. ${ }^{3}$ The discrepancy does not appear to be attributable to treatment since both our study and that of Binet investigated treated and untreated patients, and since we were unable to detect significant differences between these groups. It is possible, however, that differences in the staging systems used may be relevant; in Binet's staging the clinical picture of splenomegaly and lymphadenopathy without anaemia or thrombocytopenia is regarded as advanced disease (stage III), while this is classified as stage II disease in the Rai system, which we used.

Our Hemalog D analysis of minor leucocyte types in CLL yielded unexpected results. Thus, even in advanced disease manifested by anaemia and thrombocytopenia, no impressive reduction of neutrophils, eosinophils, or basophils was observed; furthermore, treatment seemed to have little effect on the numbers of these cell types. Profound monocytopenia was observed in some cases, but was not a consistent feature except in stage IV disease. We cannot explain these results, but they provide an interesting contrast with those in HCL. This study showed that HCL was characterised by a markedly higher percentage of LUCs than CLL. This is probably attributable both to the large size of hairy cells ${ }^{12}$ and to the scattering of light by their surface hairs. The high percentage of LUCs in HCL may also be in part the result of the stickiness ${ }^{13}$ of hairy cells, causing the passage of pairs of cells through the optical detector; this may explain the double lymphoid population observed in one of our HCL patients. Our Hemalog D study confirmed the presence in HCL of consistent neutropenia and monocytopenia noted by other authors using conventional microscopical methods. ${ }^{13}$ These findings were in marked contrast to those in CLL with apparently similar heavy bone marrow infiltration. Our Hemalog D study showed no depression of eosinophils and basophils in HCL. The explanation of these findings is uncertain, but they may imply the presence in HCL of factors that specifically inhibit the common neutrophil/monocyte progenitor cell.

The cases of PLL had a high percentage of LUCs comparable with that in HCL, but were distinguished by the absence of neutropenia and monocytopenia. These Hemalog $D$ findings agree with those of Costello et al. ${ }^{14}$ who, using the Coulter Channelyser showed that the cells of HCL and PLL have a higher mean cell volume than CLL cells. The small number of cases with lymphoplasmacytoid morphology and with Sézary's syndrome had a moderately raised percentage of LUCs, comparable with that seen in CLL.

In conclusion, although the Hemalog D does not seem to provide useful prognostic information in CLL, it can readily distinguish this disease from hairy-cell leukaemia and prolymphocytic leukaemia.

We thank the Technicon Instrument Company (International Division) for assistance throughout this project. We are most grateful for blood samples and clinical information provided by the following haematologists: Dr BE Roberts, General Infirmary, Leeds; Dr GA Marsh, Dr TO Kumaran, North Middlesex Hospital; Dr DS Thompson, Luton and Dunstable Hospital; Dr BT Colvin, London Hospital; Dr J Steadman, Barking Hospital; Dr PA Clark, Barnet General Hospital; Dr PM Roberts, Dr A Baughan, St Albans City Hospital; Dr D Catovsky, Hammersmith Hospital. We also thank Miss Paula Richardson for typing the manuscript.

\section{References}

${ }^{1}$ Rai KR, Sawitsky A, Cronkite EP, Chanana AD, Levy AN, Pastenack BS. Clinical staging of chronic lymphocytic leukemia. Blood $1975 ; 46: 219-34$.

${ }^{2}$ Binet JL, Le Porrier M, Dighiero G, et al. A clinical 
staging system for chronic lymphocytic leukemia. Cancer 1977;40:855-64.

${ }^{3}$ Binet JL, Vaugier G, Dighiero G, D'Athis P, Charron D. Investigation of a new parameter in chronic lymphocytic leukemia: the percentage of large peripheral lymphocytes determined by the Hemalog D. Am J Med 1977;63:683-8.

4 Mansberg HP, Saunders AM, Groner W. The Hemalog D white cell differential system. J Histochem Cytochem 1974;22:711-24.

5 Patterson KG, Cawley JC, Goldstone AH, Richards JDM, Janossy G. A comparison of automated cytochemical analysis and conventional methods in the classification of acute leukaemia. Clin Lab Haematol $1980 ; 2: 281-91$.

- Gray JL, Jacobs A, Block M. Bone marrow and peripheral blood lymphocytosis in the prognosis of chronic lymphocytic leukemia. Cancer 1974;33:1169-78.

? Dubner HN, Crowley JJ, Schilling RF. Prognostic value of nucleoli and cell size in chronic lymphocytic leukemia. Am J Hematol 1978;4:337-41.

${ }^{8}$ Scott RB. Leukaemia. Lancet 1957;i:1162.

- Peterson LC, Bloomfield CD, Swadberg RD, GajlPeczalska KJ, Brunning RD. Morphology of chronic lymphocytic leukemia and its relationship to survival.으 Am J Med 1975;59:316-24.

10 Peterson LC, Bloomfield CD, Brunning RD. Relationship of clinical staging and lymphocyte morphology to survival in chronic lymphocytic leukaemia. BrJ Haemato $1980 ; 44: 563-7$.

11 Debauche R. Evaluation of the utilization of the Hemaloge $D$ system in a hospital clinical laboratory. Technicon International Colloquium, Paris, 1976.

12 Braylan RC, Jaffe ES, Triche TJ, et al. Structural and functional properties of the "hairy" cells of leukemicreticuloendotheliosis. Cancer 1978;41:210-27.

13 Cawley JC, Burns GF, Hayhoe FGJ. Hairy-cell leukemia. Heidelberg: Springer-Verlag, 1980.

14 Costello C, Wardle J, Catovsky D, Lewis SM. Cel尺 volume studies in B-cell leukaemias. $\mathrm{Br} J$ Haematof $1980 ; 45: 209-14$.

Requests for reprints to: Dr KG Patterson, Departmento of Haematology, University College Hospital, Gower Street, London WC1E 6AU, England. 